\title{
Professional Development of Mathematics Teachers with Lesson Study and Open Approach: The Process for Changing Teachers Values about Teaching Mathematics
}

\author{
Thanya Kadroon ${ }^{1}$, Maitree Inprasitha ${ }^{2}$ \\ ${ }^{1}$ Doctoral Program in Mathematics Education, Faculty of Education, Khon Kaen University, \\ KhonKaen, Thailand \\ ${ }^{2}$ Center for Research in Mathematics Education, Faculty of Education, Khon Kaen University, \\ KhonKaen, Thailand \\ Email: kadroon_crme@kku.ac.th
}

Received December 4 ${ }^{\text {th }}$, 2012; revised December 31 $1^{\text {st }}$ 2012; accepted January 21 $1^{\text {st }}, 2013$

\begin{abstract}
The aim of this study was to analyze the process for changing values about teaching mathematics for teachers in a pilot school implementing Lesson Study and Open Approach. The study was structured through a questionnaire survey of 83 teachers in 4 pilot schools. Case studies were then conducted with 3 of the teachers and involved participatory observations and video recording in 3 phases of Lesson Study, interviews and document analysis. Theoretically, the conceptualization of professional development with Lesson Study and Open Approach, values change (Rescher, 1969 cited in Seah, 2004) and change process (Fullan, 1985; Joyce \& Showers, 1980) helps to explain the process for changing values about teaching mathematics. The study shows that teachers in a pilot school implementing Lesson Study and Open Approach have developed a new view and values about teaching mathematics (e.g. values in designing lesson plans, values in teaching practice, values in classroom assessment). The components were essential for changing teachers values about teaching mathematics and consisted of 1) Teachers participating and learning about the underlying theoretical principles of Lesson Study and Open Approach 2) Practicing weekly cycles of Lesson Study into school culture 3) Seeing Lesson Study and Open Approach demonstrated from expert and Japanese teachers 4) Ongoing coaching or support from the project and 5) Obtaining feedback from outsiders such as educators, parents, school board members etc.
\end{abstract}

Keywords: Professional Development; Community of Practice; Lesson Study; Open Approach; Values about Teaching Mathematics

\section{Introduction}

Professional development can be modeled in a various ways. Some researchers view professional development as a "training model" and other researchers view "the sociocultural model" (Johnson, Lustick, \& Kim, 2011). It seems that neither one may be able to reveal a complete picture of professional development and a system-wide improvement of education. In this study, Lesson Study and Open Approach were used as an innovation for a school-based professional development system. Lesson Study refers to a major form of professional development and professional learning chosen by Japanese teachers, an approach to instructional development, and also provides a powerful mechanism for a system-wide improvement of education that has spread rapidly in North America and other countries (Stigler \& Hiebert, 1999; Fernandez \& Yoshida, 2004; Wang-Iverson \& Yoshida, 2005; Baba, 2007; Inprasitha, 2010; Lewis, 2002, 2011).

Thailand has been implementing Lesson Study since 2002. An adaptive feature of this implementation is to incorporate Open Approach as a teaching approach into Lesson Study processes (Inprasitha, 2010). Teaching is a cultural activity (Stigler \& Hiebert, 1999) and because of the different cultural backgrounds and also values about teaching mathematics between Thai teachers and Japanese teachers, it is not to easy to implement Lesson Study and Open Approach in Thai schools as mentioned by Inprasitha (2010). Values are very important in research studies and teachers' professional development since the values which teachers of mathematics bring to various aspects of their work profoundly affect what and how they teach, and therefore what and how their students learn. Mathematics classrooms can be regarded as places where values are expressed, communicated and learned (Bishop et al., 2003).

In exploring values encountered in mathematics classrooms, Bishop (1996, 1998, 2001a cited in Bishop et al., 2003) identified three categories of values of interest-general educational, mathematical and mathematics educational. Mathematical values: values which have developed as the knowledge of mathematics have developed within any particular culture. General educational values: values associated with the norms of the particular society and of the particular educational institution. Mathematics educational values: values embedded in the curriculum, textbooks, classroom practices, etc. as a result of the other sets of values (Bishop, 2007). Teacher reflection on their pedagogical decisions and actions represents a complementary approach to finding out what is valued and considered important by the teacher. Such decisions are made, and actions demonstrated in various aspects of our professional lives as teachers, from lesson planning to lesson execution and to assessment (Seah, 2002). In my work I have used Seah's (2002) ideas to 
consider values about teaching mathematics-values in designing lesson plans, values in teaching practice and values in classroom assessment.

Values are expressed through views and behavior (Veugelers \& Kat, 2000). Changing the behavior of others by repeating and reinforcing behaviors that they develop into patterns and habits which can ultimately lead to changed values (Listenberger, 2004). Change is a process and there are four broad phases in the change process: initiation, implementation, continuation, and outcome (Fullan, 1982, 1991). Any recommendation for changing teaching invariably carries with it the implication of a change in the values being taught. Any significant development in mathematics education probably implies a change in values (Bishop et al., 2003).

Researching values development or values change is no easy matter, but Lesson Study is an excellent method for studying the development or change of values in the classroom. In Lesson Study cycle, it would be necessary to plan together with the teachers what values they would try to develop and what values they thought they were going to develop. To observe and recorded the lessons and interviewed the teachers after the lessons to have them explain what they thought they had achieved (Bishop, 2007). The differences between teachers' professional development with Lesson Study and traditional professional development in Table 1. will set up values conflicts but for this reason Bishop and Seah mentioned that it will be a crucial point to observe teachers solving the values conflict leading to values change and also educational change as the need of educational reform is calling for changes in teaching practices from a traditional teaching style to emphasize students' learning process and attitudes toward learning with understanding (Office of the Education Council (OEC), 2008; Forman, 1996; Inprasitha, 2010). There are many crucial aspects of the educational reform movement; professional development of teachers is a central issue. Teachers need to learn how to capture students' learning processes and to examine their own practice. Lesson Study and Open Approach are a comprehensive and well-articulated process for examining practices (Inprasitha, 2010).

\section{Professional Development of Mathematics Teachers with Lesson Study and Open Approach in the Thai Context}

Lesson Study as a Japanese teaching professional development has been developed and used in Japan for more than 130 years. Now, it is expanded throughout the world for improving teacher's profession. During the years 2006-2008, Thailand and Japan have jointly led "Lesson Study" in teacher professional

Table 1.

Contrasting views of professional development. By Lynn Liptak (cited in Lewis, 2002).

\begin{tabular}{cc}
\hline Traditional & Lesson study \\
\hline Begins with answer & Begins with question \\
Driven by outside “expert” & Driven by participants \\
Communication flow: & Communication flow: \\
trainer to teacher & among teacher \\
Hierarchical relations between trainer & Reciprocal relations among learner \\
\& learners & Practice is research \\
\hline
\end{tabular}

development under the APEC Lesson Study project in 17 countries. Thailand as the owner of the project has implemented the project in 4 pilot schools. In order to make it easy for implementation, Lesson Study in Thai school Inprasitha (2010) started with three basic steps: collaboratively designing research lesson (Plan), collaboratively observing their friend teaching the research lesson (Do) and collaboratively doing post-discussion or reflection on teaching practice (See). An Adaptive feature of this implementation is to incorporate Open Approach as a teaching approach into Lesson Study processes. Four phases of Open approach as a teaching approach are 1) Posing openended problem; 2) Students' self learning; 3) Whole class discussion and comparison; and 4) Summarization through connecting students' mathematical ideas emerged in the classroom as show in Figure 1.

Thailand has been implementing Lesson Study since 2002 with an initiative of Inprasitha (2004) by conducting a pilot study project at the faculty of Education, Khon Kaen University, with 15 student teachers. Later on, in 2003, it was implemented in 2 schools in Khon Kaen Province. In 2006, Lesson Study was expanded for in-service teacher professional development by focusing on a whole-school approach in two schools in the lab school project of the Ministry of Education of Thailand. In addition, in 2007, another two schools participated in this project. In 2009, the Center for Research in Mathematics Education (CRME) accepted an assignment from the office of the Higher Education Commission collaborating with the Office of Basic Education Commission extending the results of implemented Lesson Study and Open Approach by creating networks with Ubonratchathani University and Chiang Mai University to extend results in 12 provinces in the northern region area and the north-eastern region of Thailand including 19 schools. These extended results followed the government policy allowing the implementation for extending the national findings in 2010 school year (Inprasitha, 2009).

In this project, Open Approach as a teaching approach was incorporated in Lesson Study and has been implemented. The idea of integrating Open Approach into the three steps of Lesson Study; collaboratively plan the lesson together for creating lesson plans with emphasis on creating "open-ended problems" in terms of 3 - 4 short instructions, teachers have to anticipate the students' responses to their instructions, and bring to discussion at the end of the week. In a sense, Open Approach is used as a subject matter of Lesson Study and Lesson Study is used as the tool for creating "open-ended problems" in this implementation (Kadroon \& Inprasitha, 2011; Inprasitha, 2012).

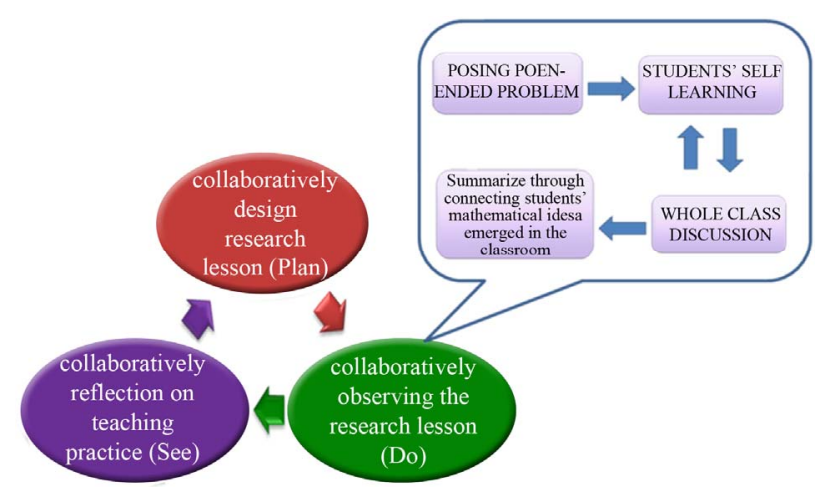

Figure 1.

An adaptive feature of lesson study in Thailand (Inprasitha, 2010). 
For implementation of the first phase in the project workshops were provided for every school teacher in the project under the care of Center for Research in Mathematics Education, Khon Kean University. Then, in the second phase, the Lesson Study cycle was implemented in schools starting from preparation/planning every Monday or Tuesday after $3 \mathrm{pm}$, application in classroom planning team came to observe class and reflecting after the class every Wednesday or Thursday after 3 pm ( See Tables 2 and 3, Figures 2 and 3) and for the third phase at the end of semester, an open class and summing up of the results of implemented Lesson Study and Open Approach were conducted together at faculty of Education, Khon Kaen University.

\section{Method}

The research design is mixing methods (Brannen, 1992). The study was structured through questionnaire surveys of 83 teachers in 4 pilot schools including Koo Kham Pittayasan School, Chumchon Ban Chonnabot School, Banbeungniam Beungkrainoon School and Nongtoom Nongngulueam School. Case studies were then conducted with 3 mathematics teachers from the 1st grade, 4th grade and 7th grade. Koo Kham Pittayasan School was in the first group of schools to join the project in 2006 and is still implementing Lesson Study and Open Approach gradually and involving participatory observations and video recording in the 3 phases of Lesson Study (Collaboratively designing research lesson, Collaboratively observing their friends teaching the research lesson and Collaboratively doing postdiscussion or reflection on teaching practice), interviews with teachers and students, and document analysis. Theoretically, the conceptualization of professional development with Lesson Study and Open Approach, value changes (Rescher, 1969 cited in Seah, 2004) and process changes (Fullan, 1985; Joyce \& Showers, 1980) helps to explain the process for changing values about teaching mathematics.

\section{Results}

The results of the study from document analysis, questionnaire, participatory observations, video recordings and interviews of teachers and students found teacher professional development with Lesson Study and Open Approach was different from Thai traditional teacher professional development which often used short term training and have no continuous monitoring. Teacher professional development with Lesson Study and Open Approach lead teachers is needed to create a new culture in the school system that emphasizes the "collaborative" and brings about change for both teachers and students as show in Table 4.

And also found changes in teachers' values about teaching mathematics (e.g. values in designing lesson plan, values in teaching practice, and values in classroom assessment). Teacher's values in designing lesson plan such as value collaboration with a team working in designing lesson plan, value lesson plan that can be applied to teach in the real classroom also value collecting data in the classroom for designing lesson plan and value the lesson plan in which students can participate and stimulate their thinking. Teacher's values in teaching practice such as value teaching approach that be hands on activity and can generate their body of knowledge with themselves, value classroom observation and reflection after class as a tool for improve

Table 2.

Weekly cycle of lesson study in Thai school.

\begin{tabular}{|c|c|c|}
\hline \multicolumn{3}{|c|}{ Weekly cycle detailed (case study: Koo Kham Pittayasan School) } \\
\hline Activity & Date/time/place & Participant \\
\hline Collaboratively design research lesson (Plan) & $\begin{array}{l}\text { Date: every Monday and Tuesday } \\
\text { Time: after } 3 \text { pm } \\
\text { Place: at Koo Kham Pittayasan school meeting room }\end{array}$ & $\begin{array}{l}\text { Mathematics teacher } \\
\text { Observer teacher } \\
\text { Internship student }\end{array}$ \\
\hline Collaboratively observing their friend teaching the research lesson (Do) & Depends on timetable in each class & $\begin{array}{l}\text { School coordinator school } \\
\text { Principal supervisor }\end{array}$ \\
\hline Collaboratively doing post-discussion or reflection on teaching practice & $\begin{array}{l}\text { Time: after } 3 \text { pm } \\
\text { Place: at Koo Kham Pittayasan School meeting room }\end{array}$ & Outside expert \\
\hline
\end{tabular}

Table 3.

Observing team (Case study: 3 classrooms from Koo Kham Pittayasan School).

\begin{tabular}{cll}
\hline Team & \multicolumn{1}{c}{ Teacher } & \multicolumn{1}{c}{ Observer } \\
\hline \multirow{4}{*}{ 1st Grade } & 1st Grade & Science teacher (1) \\
& Mathematics teacher & 1st Grade Internship student (2) \\
& & School coordinator (3) \\
& & School principal, Supervisor, Researcher team, Outside expert (4) \\
& & 5th Grade Mathematics teacher (1) \\
\multirow{4}{*}{ 4th Grade } & 4th Grade & 4th Grade Internship student (2) \\
& Mathematics teacher & School coordinator (3) \\
& & School principal, Supervisor, Researcher team, Outside expert (4) \\
& & English teacher (1) \\
7th Grade & 7th Grade & 7th Grade Internship student (2) \\
& Mathematics teacher & School coordinator (3) \\
& & School principal, Supervisor, Researcher team, Outside expert (4) \\
\hline
\end{tabular}

Note: Observer (1)-(3) Attend and observe regularly. Observer (4) Attends and observes sometimes. 

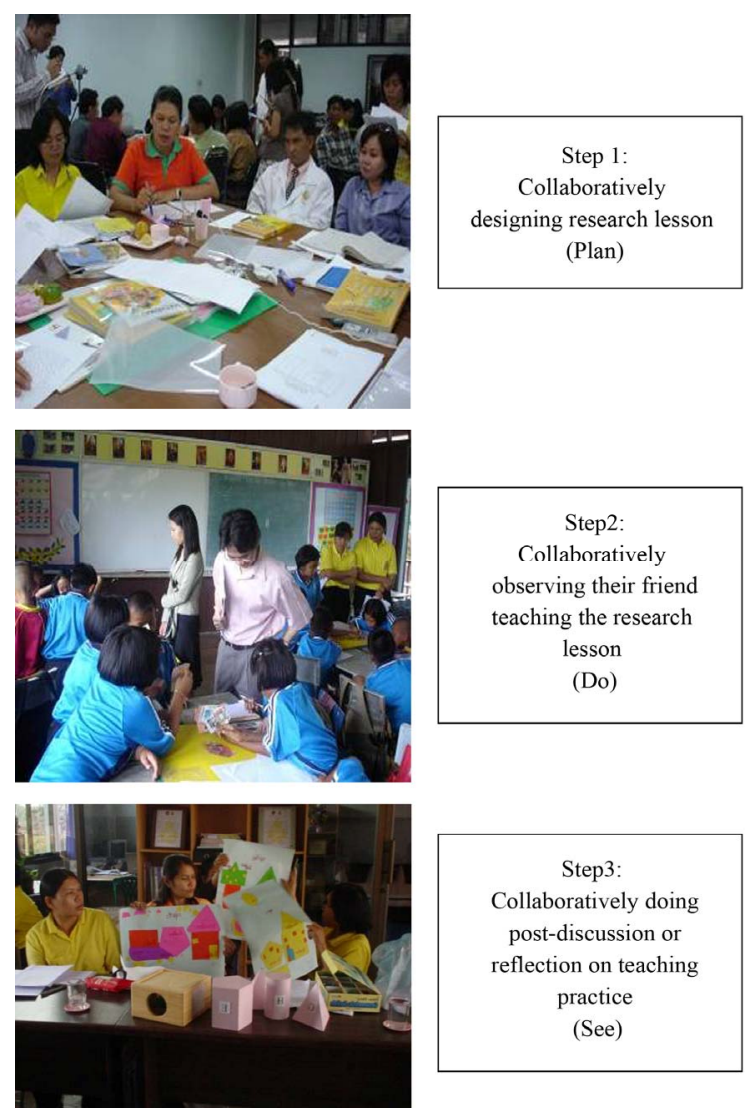

Figure 2.

Implemented lesson study in Thai school system (Koo Kham Pittayasan School). their teaching. Teacher's values in classroom assessment such as value the evaluation method that corresponds with the teaching method, value classroom observation and reflection after class as a tool for assessment to improve their teaching.

The components were essential for change processes consisting of 1) Teachers participating and learning about the underlying theoretical principles of Lesson Study and Open Approach; 2) Practicing weekly cycles of Lesson Study and incurporating into school culture; 3) Seeing Lesson Study and Open
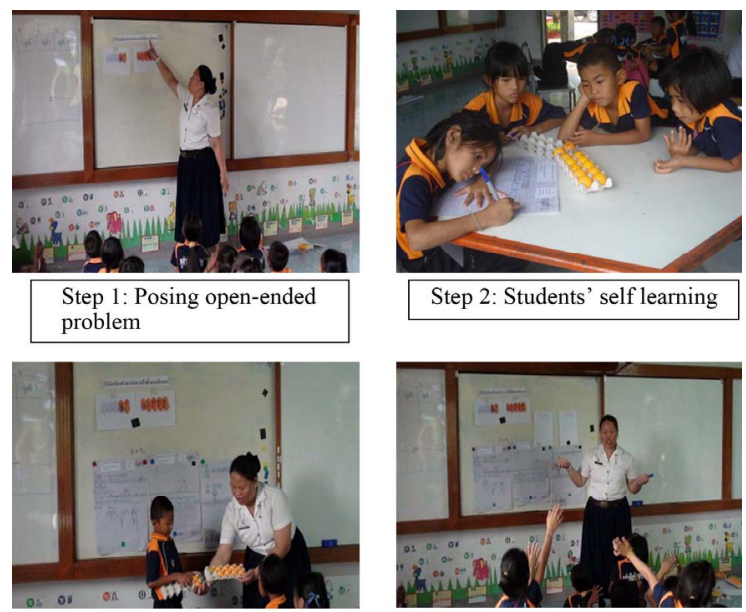

Step 3: Whole class

discussion and comparison

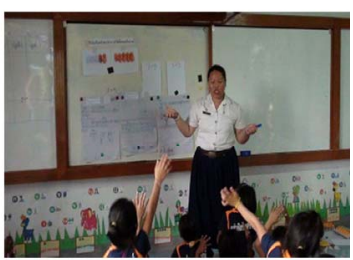

Step 4: Summarization

through connecting students mathematical ideas emerged in the class room

Figure 3.

4 Steps of open approach as a teaching method in a Thai classroom (Koo Kham Pittayasan School).

Table 4.

Teachers' change and students' change.

Case study $\quad$ Teacher's change (from teacher's view and peer view)

"I have changed the teaching methods from explaining and directing to stimulating the students' idea”

"I value student- centered instruction and

1st grade mathematics teacher

4th grade mathematics teacher

7 th grade mathematics teachers

learning by themselves”

"The role of the teacher is observation and taking note of students' behavior while they are solving the problem”

"Teachers modify the teaching methods from explaining the content, the rule or principles to listening to the student” confident with their role”

"Be a teaching approach where teachers have to prepare
"Teachers develop their own teaching strategies and have more themselves for all aspects, such as preparing the plan. We have to discuss with the team. During teaching practices we have to "Student have a systematic analysis and have a

stimulate students, observe and take note of student's ideas also reasoning in their thinking” note the real problems in the classroom for discussion and share with other teachers and the team after class. This process will help the teacher with lesson development."
Student's change (from teacher's view and peer view)

"Student adapt their learning from following teacher command to inquiry and exploration to find an answer for themselves"

"Learning with hands on experience and happiness"

"Students have a systematic analysis and have a reasoning in their thinking”

"Students learning to work with peers and team”

"Students have more confidence in their thinking and speaking"

"Students have more confidence in their thinking and speaking"

"Students have learning to work with peer and team"

"Learning with hands on experience and happiness"

"Student have a systematic analysis and have a reasoning in their thinking”

"Students learn to work with peers and team"

"Students have more confidence in their thinking and speaking”

"Students have more participation in learning activities" 
Approach demonstrated by expert and Japanese teachers; 4) Ongoing coaching or support from the project; and 5) Obtaining feedback from outsiders such as educators, parents, school board members etc.

\section{Conclusion}

The efforts in applying an innovation such as Lesson Study and Open Approach into Thai school context and shifting from the traditional professional development where emphasis is on short term training to emphasizing the collaboration of teachers in the school system to creating a community of good practice. In the beginning, the school situation was analyzed and training workshops for teachers in school were implemented. The implementation process of Lesson Study and Open Approach continued in the week. Specialists from Thailand and from abroad were invited to educate teachers on a regular basis. Teachers had the opportunity to have open class at the end of the semester and include an opportunity for agencies and organizations to visit the class. All of these processes help teachers to modify patterns of teaching, learning habits and culture in the workplace and also to gain a perspective on teaching mathematics. It can be said that teachers have developed a new view on how to teach mathematics and how to view and evaluate the class. These processes have contributed to the process of changing values about teaching mathematics for teachers. As Inprasitha (2010) mentioned, introducing Lesson Study into Thai schools has much influence not only for improving teaching practice in schools, but also for improving the system of teacher education as a whole.

\section{Acknowledgements}

This research is supported by the Commission on Higher Education and also Center for Research in Mathematics Education, Khon Kaen University, Thailand.

\section{REFERENCES}

Baba, T. (2007). Japanese education and lesson study: An overview Section 1.1: "How is lesson study implemented". In M. Isoda, M. Stephens, Y. Ohara, \& T. Miyakawa (Eds.). Japanese lesson study in mathematics (pp. 2-7). Singapore City: World Sciencetific Publishing.

Bishop, A. J.; Seah, W. T., \& Chin, C. (2003). Values in mathematics teaching-The hidden persuaders? In A. J. Bishop et al. (Eds.), Second international handbook of mathematics education. Part. 1 and 2 (pp. 717-765). Dordrecht: Kluwer Academic publishers.

Bishop, A. J. (2007). Teacher's mathematical values for developing mathematical thinking through lesson study. APEC-KHON KAEN International Symposium 2007 Innovative Teaching Mathematics through Lesson Study (II)_-Focusing on Mathematical Thinking.

Brannen, J. (1992). Mixing methods: Qualitative and quantitative research. Aldershort: Gower.

Fernandez, C., \& Yoshida, M. (2004). Lesson study: A Japanese approach to improving mathematics teaching and learning. Lodon: Lawrence Erlbaum Associates.
Forman, E. A. (1996). Learning mathematics as a participation in classroom practice: Implications of sociocultural theory for educational reform. In L. P. Steffe, P. Nesher, P. Cobb, G. A. Goldin, \& B. Greer (Eds.), Theories of mathematical learning (pp. 115-130). Mahwah, NJ: Lawrence Erlbaum.

Fullan, M. (1985). Change process and strategies at the local level. The Elementary School Journal, 85, 391-421. doi:10.1086/461411

Inprasitha, M. (2010). One feature of adaptive lesson study in Thailand: Designing learning unit. Proceedings of the 45th Korean National Meeting of Mathematics Education. Gyeongju: Korean Society of Mathematics Education, 8-10 October 2010.

Inprasitha, M. (2012). Lesson study as an innovation for teacher professional development: A decade of Thailand experience. URL (last checked 18 December 2012).

http://www.mathematik.uni-dortmund.de/ieem/bzmu2012/files/BzM U12_0275_Inprasitha.pdf

Inprasitha, N. (2009). Lesson study: An innovation for teacher and student development. Unpublished PhD Dissertation, Khonkaen: Khon Kaen University.

Johnson, W., Lustick, D., \& Kim, M. J. (2011). Teacher professional learning as the growth of social capital. Current Issues in Education, 14. http://cie.asu.edu/ojs/index.php/ cieatasu/article/view/781

Joyce, B., \& Showers, B. (1980). Improving in-service training: The messages from research. Educational Leadership, 37, 379-385.

Kadroon, T., \& Inprasiha, M. (2011). Teachers’ values about teaching mathematics in classrooms; Implementing lesson study and open approach: A Thai experience. Journals of the Korean Society of Mathematics Education Series D, 15, pp. 115-126.

Lave, J., \& Wenger, E. (1998). Communities of practice: Learning, meaning, and identity. Cambridge: Cambridge University Press.

Lewis, C. (2002). Lesson study: A handbook of teacher-led instructional change. Philadelphia, PA: Research for Better Schools.

Lewis, C. \& Hurd, J. (2011). Lesson study step by step: How teacher learning communities improve instruction. Portsmouth: Heinemann.

Listenberger, M. (2004). Process centered leadership. URL (last checked 18 December 2012).

http://www.stxd.org/PGI/Web\%20Workshops/Process_centered_lea dership.pdf

Office of the Education Council (OEC) (2008). Education in Thailand 2007 (Online). Bangkok: Thailand Ministry of Education. URL (last checked 6 November 2010).

http://www.onec.go.th/onec_administrator/uploads/Book/759-file.pdf

Seah, W. T. (2002). Exploring teacher clarification of values relating to mathematics education. In C. Vale, J. Roumeliotis \& J. Herwood (Eds.). Valuing mathematics in society (pp. 93-104). Brunswick: Mathematical Association of Victoria.

Seah, W. T. (2004). The negotiation of perceived value differences by immigrant teachers of mathematics in Australia. Unpublished PhD Dissertation, Victoria: Monash University.

Stigler, J. W., \& Hiebert, J. (1999). Teaching gap: Best ideas from the world's teachers for improving Education in the classroom. New York: Free Press.

Veugelers, W., \& Kat, E. D. (2000). The teacher as a moral educator in secondary education: The student perspective. The 81st Annual Meeting of the American Educational Research Association, New Orleans, 24-28 April.

Wang-Iverson, P., \& Yoshida, M. (2005). Building our understanding of lesson study. Philadelphia, PA: Research for Better Schools. 